\title{
Serum Levels of Brain-Derived Neurotrophic Factor (BDNF) in Autistic Children In Central Saudi Arabia
}

\author{
Laila AL-Ayadhi*
}

Department of Physiology (29), Autism Research and Treatment Center (ART Center) (99), Al-Amodi Autism Research Chair, Faculty of Medicine, King Saud University, P.O. Box 2925, Riyadh 11461, Saudi Arabia

\begin{abstract}
Autism is a neurodevelopmental behavioral disorder with unknown etiology characterized by impairment of social contact and communication, restricted and repetitive interest and behaviors. The aim of the current study is to explore possible role of Brain-derived neurotrophic factor (BDNF) and serum myelin basic protein (MBP) auto-antibody in autism spectrum disorders. The study was conducted at the autism research \& treatment center and Al-amodi autism research chair, king Saud University. Forty six autistic children, age up to 12 years (41 males and 5 females), with confirmed diagnosis according to DSM-IV diagnostic criteria for autistic spectrum disorders, and 3DI (Dimensional, Developmental, Diagnostic Interview) participated in the study. And 53 age matched normal children, were recruited in the study. Brain-derived neurotrophic factor (BDNF), and myelin basic protein antibody, were measured by ELIZA method. Results showed that Serum levels of BDNF in autistic children expressed as mean \pm S.D were significantly lower than those of normal controls $(353.2 \pm 78 \mathrm{ng} / \mathrm{ml})$ versus $(540 \pm 57 \mathrm{ng} / \mathrm{ml})$ respectively. Nevertheless, we found no correlations between BDNF levels and clinical variables in autistic patients. On the other hand, myelin basic protein autoantibody serum levels expressed as mean \pm S.D in autistic were significantly $(\mathrm{P}<0.001)$ higher than those of agematched healthy controls $(590 \pm 27 \mathrm{ng} / \mathrm{ml})$ versus $(390 \pm 35)$ respectively. This study suggests a highly possible pathophysiological role played by BDNF and MBP in autism spectrum disorders.
\end{abstract}

Keywords: BDNF, autism spectrum disorders, MBP, immunity.

\section{INTRODUCTION}

Autism is a neurodevelopmental behavioral disorder with an onset prior to $36^{\text {th }}$ month characterized by impairment of social contact and communication, restricted and repetitive interest and behaviors [1]. Other characteristics include, sensory dysfunction, inappropriate laughing and giggling, little or no eye contact, apparent insensitivity to pain, preference to be alone and many more characteristics (American psychiatrist association) [2]. Recent epidemiological studies suggested that autism might affect one in 150 of USA children [1,2]. In the last 20 years, there has been an increase in the incidence of autism, which cannot be explained by genetics alone, nor can this increase be secondary to only increase awareness. The etiology of autism is complex, and in most cases, the underlying pathologic mechanisms are unknown [2-5].

It is now well documented that neurotrophic factors such as nerve growth factor, brain-derived neurotrophic factor, glial cell line-derived neurotrophic factor, and insulin-like growth factor, are important regulators of neuronal growth, differentiation, and survival during early brain development [6-7]. Several studies suggested the possibility of a critical role played by brain-derived neurotrophic factor (BDNF) in brain development, in particular in the pathophysiology of

*Address correspondence to this author at the Department of physiology (29), Autism Research and Treatment center (ART center) (99), Al-Amodi Autism Research Chair, Faculty of Medicine, king Saud University, P.O. Box 2925, Riyadh 11461, Saudi Arabia; Tel: +966504295974; Fax: +96614786798// +96614672567; E-mail: ayadh2@gmail.com psychiatric diseases, including mood disorders and schizophrenia [6-9]. On the other hand, there is a conflicting result regarding the role played by BDNF in autism, Nelson and his group in 2001 and Miyazaki and co-workers in 2004, demonstrated higher BDNF levels in blood samples obtained from children with autism compared to normal controls [10, 11]. In contrast Hashimoto and his associates demonstrated the opposite [12]. For this reason, the purpose of the current study, therefore, was to examine whether serum levels of $\mathrm{BDNF}$ are altered in autistic children compared to control in central Saudi Arabia.

\section{MATERIALS AND METHODS}

The study was conducted at the autism research \& treatment center, Al-Amodi Autism Research Chair, King Saud University, between January to July 2010. Forty six autistic children, age up to 12 years (41 males and 5 females), with confirmed professional diagnoses were selected. The mean age of the total number of children who participated in the study was $7.4 \pm 0.9$ years (Table 1). The diagnosis was done either by qualified psychologist or psychiatrist of neurologist, according to diagnostic criteria DSM-IV (2) and 3DI (Dimensional, Developmental, and Diagnostic Interview). A complete diagnostic workup including medical, neurological, psychiatric and psychological evaluation was done for all of the studied children with autism. Fifty three, healthy age and sex matching control (46 male and 7 females), with mean age $8.4 \pm 0.5$ years (Table 1), were recruited from King Abdul Aziz University Hospital. Exclusion criterias for autistic patients and healthy volunteers were subjects suffering from 
Table 1. The Study of Autism Spectrum Disorder

\begin{tabular}{|l|l|l|}
\hline & $\begin{array}{l}\text { Children with Autism Spectrum } \\
\text { disorders }\end{array}$ & Control subjects \\
\hline \hline Total No. Participated. & 46 & 53 \\
\hline $\begin{array}{l}\text { Sex } \\
\text { Male }\end{array}$ & 41 & 46 \\
Female & 5 & 7 \\
\hline Age (years mean \pm SD) & $7.4 \pm 0.9$ & $8.4 \pm 0.5$ \\
\hline Diet & Normal diet & Normal diet \\
\hline Medication & Not on medication & Not on medication \\
\hline
\end{tabular}

a neurological, inflammatory, endocrine or clinically significant chronic disease; immunocompromised subjects; subjects with tuberous sclerosis, and subjects receiving medication with known or potential interaction with immune system. A written consent was obtained from the parents of each individual case, according to the guidelines of the ethical committee of King Khaled University Hospital.

Blood samples were collected by venipuncture in plain tubes, and after gentle mixing were allowed to clot at room temperature, and then centrifuged at $1,500 \mathrm{~g}$ for 10 minutes. Then serum was collected and stored at $-70^{\circ} \mathrm{C}$ until assay time. Samples were assayed in a single large batch, in duplicates. Serum Brain-derived neurotrophic factor concentrations were measured using a commercially available, sandwich enzyme immunoassay (ELISA) kit from Emax Immunoassay System (Promega Corp., Madison, Wisconsin). Myelin basic protein serum auto antibodies levels were measured by commercially available, sandwich enzyme immunoassay (ELISA) kit from Diagnostic Systems (Texas, USA). Computer SPSS program was used and results were expressed as mean \pm SD. All statistical compression was made by means of independent T-test with $\mathrm{P}$ values equal to or less than 0.05 were considered as significant.

\section{RESULTS}

Forty six autistic children with confirmed diagnosis, age up to 12 years (41 males and 5 females) participated in the study, and fifty three age matched control. The mean age of the total number of children who participated in the study was $7.4 \pm 0.9$ years. Data of serum BDNF and MBP autoantibody followed a normal distribution (parametric) by Kormogorov-Smirnov test of normality. Serum levels of BDNF are shown in figure. Serum BDNF levels in patients with autism $((353.2 \pm 78 \mathrm{ng} / \mathrm{ml})$ (mean \pm S.D. $)$ ) were significantly $(\mathrm{P}<0.001)$ lower than those of age-matched healthy controls $((540 \pm 57 \mathrm{ng} / \mathrm{ml})($ mean $\pm \mathrm{S} \mathrm{D}))$. There was no correlation between serum BDNF and severity of autism. In addition, there were no significant differences in BDNF serum levels among autistic males compared to autistic females (Fig. 1).

On the other hand, myelin basic protein auto-antibody serum levels in autistic $((590 \pm 27 \mathrm{ng} / \mathrm{ml})($ mean \pm S.D. $))$ were significantly $(\mathrm{P}<0.001)$ higher than those of age-matched healthy controls $(390 \pm 35 \mathrm{ng} / \mathrm{ml})$ (mean \pm S.D.)) (Fig. 2).

\section{DISCUSSION}

The current study demonstrated statistically significant, lower serum level of BDNF in autistic compared to age and

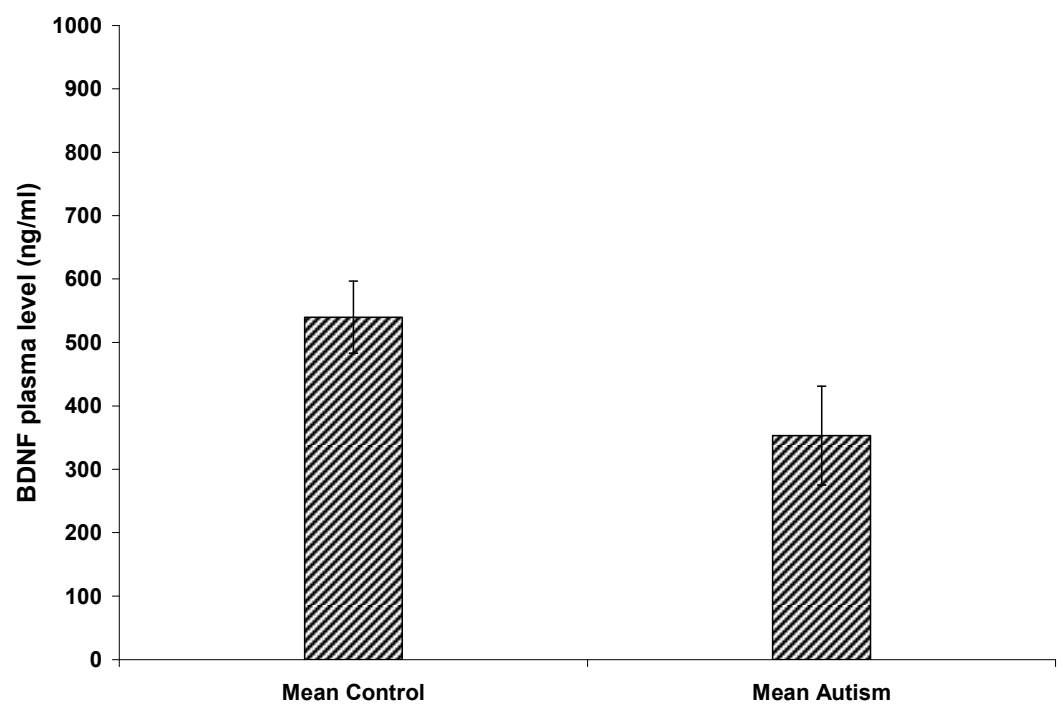

Fig. (1). Serum levels of BDNF $(353.2 \pm 78 \mathrm{ng} / \mathrm{ml})$ were significantly $(\mathrm{P}<0.001)$ lower than those of age-matched healthy controls $(540 \pm 57$ $\mathrm{ng} / \mathrm{ml})$. Values are mean $\pm \mathrm{SD}$, expressed as means of independent T-test with $\mathrm{P}$ values equal to or less than 0.05 considered as significant. 
sex matched control children who participated in the study. BDNF serum levels were not related to the severity of autism. Furthermore, our results demonstrated statistically significant higher MBP auto antibody serum levels in autistic compared to healthy age and sex matched control. Our results regarding $\mathrm{BDNF}$, are in agreement with that of Hashimoto 2006 [12]. On the other hand, our data is in contrast to other studies conducted on autistic children. Such as that conducted by Miyazaki et al. 2004, Connelly et al. 2006 and Correia et al. 2010. They demonstrated higher levels of BDNF in autistic compared to controls [11, 13, 14]. Last but not least, Croen et al. in 2008, found no significant difference in BDNF concentrations between autistic and control children [15].

Over the last few years' scientists suggested that specific neurotrophins and neuropeptides present in newborn infant's blood have been shown to have predictive value in determining those children who will later have disruption of intellectual and or social development [9]. For example, neonatal concentrations of BDNF, vasoactive intestinal peptide (VIP), calcitonin gene-related peptide (CGRP), and neurotrophin 4/5 (NT4/5) were higher in children with autistic spectrum and in those with mental retardation without autism than in healthy control children [9]. Similar results were reached by others [16-18]. On the other hand our results showed the opposite, a lower level of BDNF in autistic compared to normal control children. Furthermore, keeping in mind the important role played by BDNF in neurogenesis, and consequently, our results are more sensible, and lower level of BDNF in autistic reflects a disturbed neurogenesis in those who are autistic, and subsequently disturbed brain function observed in the autistic.

Altered BDNF serum levels were observed in a variety of diseases. Serum BDNF has been shown to be decreased in depressed patients [17] and is also increased after seizures $[19,20]$. According to a study conducted by Katoh-Samba on rats [20, 21], BDNF level, increases during the first 30

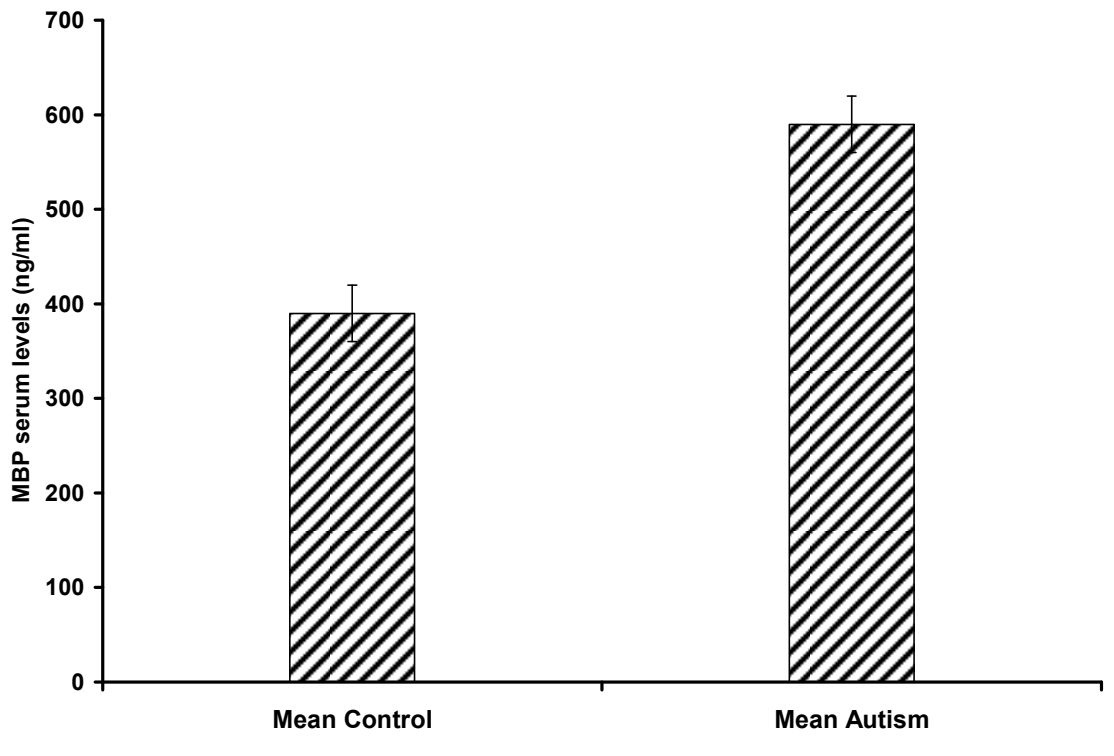

Fig. (2). Myelin basic protein auto-antibody serum levels in autistic were $(590 \pm 27 \mathrm{ng} / \mathrm{ml})$ were significantly $(\mathrm{P}<0.001)$ higher than those of age-matched healthy controls $(390 \pm 35 \mathrm{ng} / \mathrm{ml})$. Values are mean $\pm \mathrm{SD}$, expressed as means of independent T-test with $\mathrm{P}$ values equal to or less than 0.05 considered as significant. postnatal days throughout most brain regions except the hippocampus. These findings are consistent with age-related changes in serum levels in rats $[20,21]$. Thus, the brain is a candidate source for circulating BDNF. If this is true in the human case, then serum levels would be expected to increase during the postnatal development of the cortex, and differences should be found in autism because the disorder is characterized by impaired brain development. Furthermore, there is a positive correlation between serum BDNF levels and cortical BDNF levels that continues from early maturation throughout the aging process [17]. Thus, it is possible that low levels of BDNF status occur in the brain of autistic patients, and consequently lower serum levels. As it is found in our study. This can be used as an indicator of disease in autistic spectrum disorders. And in the future with further extended studies, may be of great significance, as it might help to decide the time of onset of these devastating disorders.

It has been reported that social isolation (8 weeks) selectively reduced the BDNF levels in rat hippocampus, whereas plasma corticosterone levels were not altered [22]. Suggesting that BDNF levels are responsive to psychological state [6]. Furthermore, Shimizu and co-workers in 2003, reported that serum BDNF levels in drug free patients with major depressive disorders recovered to basal levels after antidepressant treatment [23]. Therefore, it might be important to take the psychological states of subjects into consideration to unravel the role of $\mathrm{BDNF}$ in the pathophysiology of autism.

The study of autoimmunity in autism spectrum disorders gained some interest over the last few years. Our data from earlier studies, demonstrated increased autoantibodies titer to myelin basic protein in autistics, but not in healthy sex and aged matched control [24]. Furthermore, our data demonstrated increased antibody titer to mumps rubella and measles in autistic compared to age and sex matched healthy controls. Several immunologic studies show T-cell dysfunction or abnormal numbers of $\mathrm{T}$-cells in a proportion 
of autistic patients [24-29]. Central nervous system targets of autoantibodies include myelin basic protein [24, 30], and neurofilament protein $[27,31]$.

Moreover, children with autism in the current study, showed elevated serum level of MBP autoantibody, reflecting a disturbed immune system, and the initiation of autoimmune status. At this stage it is quite difficult to figure out which one started first and lead to the other, is it an immune system disturbance that resulted in disturbed neurogenesis, or the opposite. A reasonable explanation is that an immune system disturbance manifested as higher level of autoantibodies to MBP, resulted in disturbed neuronal growth displayed as lower level of BDNF and consequently disturbed neuronal function presented as the autistic symptoms.

It is quite important to keep in mind that these neuropeptides and autoantibodies could possibly play an important role in the pathogenesis of autism, or may perhaps be serological markers, for children who will go on to develop these disorders. Even if these proteins or autoantibodies are only markers of disease, their presence prior to the time of clinical diagnosis may permit earlier recognition and possibly earlier treatment intervention. It is strongly recommended at this stage to conduct the study on larger autistic population, to gain better knowledge and understanding of the important role played by neuropeptides and autoantibodies in the behavior pattern of autistic children.

Considering the significant role of BDNF in brain development, our findings lead us to the hypothesis that decreased levels of BDNF in the brain may contribute to the pathophysiology of autism. It is, therefore, of great interest to measure serum BDNF levels in infants, and follow them up, to determine the role of BDNF as a serological marker in children who will go on to develop an autistic disorder.

\section{CONCLUSIONS}

The present study demonstrated the possible critical role played by BDNF in ASD, particularly in relation to autoimmunity. Larger studies are strongly recommended, to investigate the significant role played by BDNF in ASD phenotypes. The identification of biochemical markers related to autism would be beneficial for earlier clinical diagnosis and intervention.

\section{ACKNOWLEDGEMENT}

The author wishes to thank all the children and parents who participated in the study, without whom it was not possible to conduct the study. Special thanks to King Abdul Aziz City for Science and Technology (KACST); and Alamodi autism research chair for funding the project.

\section{REFERENCES}

[1] Trottier, G.; Srivastava, L.; Walker, C.D. Etiology of infantile autism. A review of recent advances in genetic and neurological research. J. Psychiatr. Neurosci., 1999, 24, 103-115.

[2] American Psychiatric Association, Diagnostic and Statistical Manual-Text Revision (DSM-IV-TR TM), American Psychiatric Association, Washington, DC; 2000.

[3] Bailey, Le Couteur, A.; Gottesman, I.; Bolton, P.; Simonoff, E.; Yuzda, E. Rutter M. Autism as a strongly genetic disorder Evidence from a British twin study. Psychol. Med., 1995, 25, 6377.
Baird, Charman, T.; Baron-Cohen, S.; Cox, A.; Swettenham, J.; Wheelwright, S. Drew A. A screening instrument for autism at 18 months of age A 6-year follow-up study. J. Am. Acad. Child Adolesc. Psychiatry., 2000, 39, 694-702.

[5] Riikonen, R. Neurotrophic factors in the pathogenesis of Retts syndrome. J. Child Neurol., 2003, 18: 693-397.

[6] Hashimoto, K.; Shimizu, E.; Iyo, M. Critical role of brain-derived neurotrophic factor in mood disorders. Brain Res. Rev., 2004, 45, 104-114

[7] Angelucci, F.; Brene, S.; Mathe, A.A. BDNF in schizophrenia, depression and corresponding animal models. Mol. Psychiatry, 2005, 10, 345-352.

[8] Berton, O.; Nestler, E. J. New approaches to antidepressant drug discovery: beyond monoamines. Nat. Rev. Neurosci., 2006, 7, 137151

[9] Nelson, K.B.; Grether, J.K.; Croen, L.A.; Dambrosia, J.M.; Dickens, B.F.; Jelliffe, L.L. Neuropeptides and neurotrophins in neonatal blood of children with autism or mental retardation. Ann. Neurol., 2001, 49, 597-606.

[10] Nelson, P.G.; Kuddo, T.; Song, Y.E.; Dambrosia, J.M.; Kohler, S.; Satyanarayana, G. Selected neurotrophins, neuropeptides, and cytokines: developmental trajectory and concentrations in neonatal blood of children with autism or Down syndrome. Int. J. Dev. Neurosci., 2006, 24, 73-80

[11] Miyazaki, K.; Narita, N.; Sakuta, R.; Miyahara, T.; Naruse, H.; Okado, N. Serum neurotrophin concentrations in autism and mental retardation: a pilot study. Brain Devel., 2004, 26, 292-295.

[12] Hashimoto, K.; Iwata, Y.; Nakamura, K.; Tsujii, M.; Tsuchiya, K.J.; Sekine, Y. Reduced serum levels of brain-derived neurotrophic factor in adult male patients with autism. Progress in Neuro-Psychopharmacol. Biol. Psychiatry., 2006, 30(8), 15291531

[13] Connolly, A.M.; Chez, E.; Streif, E.M.; Keeling, R.M.; Golumbek, P.T.; Kwon, J.M.; Robinson, R.G.; Neuman, R.J.; Deuel, R.M. Brain-derived neurotrophic factor and autoantibodies to neural antigens in sera of children with autistic spectrum disorders, Landau-Kleffner syndrome, and epilepsy. Biol. Psychiatry, 2006, $59,354-363$

[14] Correia, C.T.; Coutinho, A.M.; Sequeira, A.F.; Sousa, I.G.; Lourenc, L.; Venda, O.; Almeida, J.P.; Abreu, R.L.; Lobo, C.; Miguel, T.S.; Conroy, J.; Cochrane, L.; Gallagher, L.; Gill, M.; Ennis, S.; Oliveira, G.; Vicente, A.M. Increased BDNF levels and NTRK2 gene association suggest a disruption of BDNF/TrkB signaling in autism. Genes Brain Behav., 2010, 9, 841-848

[15] Croen, L.A.; Goines, P.; Braunschweig, D.; Yolken, R.; Yoshida, C.K.; Grether, J.K.; Fireman, B.; Kharrazi, M.; Hansen, R.; JudyVan de, Water. Brain-derived neurotrophic factor and autism: maternal and infant peripheral blood levels in the Early Markers for Autism (EMA) Study. Autism Res., 2008, 1(2), 130-137

[16] Connolly, A.M.; Chez, M.G.; Pestronk, A.; Arnold, S.T.; Mehta, S.; Deuel, R.K. Serum autoantibodies to brain in Landau-Kleffner variant, autism, and other neurologic disorders. J. Pediatr., 1999, 134, 607-613.

[17] Karege, F.; Perret, G.; Bondolfi, G.; Schwald, M.; Bertschy, G.; Aubry, J.M. Decreased serum brain-derived neurotrophic factor levels in major depressed patients. Psychiatr. Res., 2002, 143-148.

[18] Connolly, Chez, M.G.; Pestronk, M.; Arnold, S.; Mehta, S.; Buchanon, D. Serum autoantibodies to human temporal lobe cortex in children with epilepsyand language dysfunction. Ann. Neurol., 1997, 42, 490-495

[19] Binder, A.; Croll, S.D.; Gall, C.M.; Scharfman, H.E. BDNF and epilepsy Too much of a good thing?. Trends Neurosci., 2001, 24, 47-53.

[20] Chavko, S.; Nadi. N.S.; Keyser. D.O. Activation of BDNF mRNA and protein after seizures in hyperbaric oxygen Implications for sensitization to seizures in re-exposures. Neurochem. Res., 2002, 27, 1649-1653.

[21] Katoh-Semba, R.; Takeuchi, I.K.; Inaguma, Y.; Ito, H.; Kato, K. Brain-derived neurotrophic factor, nerve growth and neurotrophin3 selected regions of the rat brain following kainic acid-induced seizure activity. Neurosci. Res., 1999, 35, 19-29.

[22] Scaccianoce, S.; Bianco, P.D.; Paolone, G.; Caprioli, D.; Modafferi, A.M.; Nencini, P.; Aldo, Badiani. Social isolation selectively reduces hippocampal brain-derived neurotrophic factor without altering plasma corticosterone. Behav. Brain Res., 2006, $168,323-325$. 
[23] Shimizu, E.; Hashimoto, K.; Okamura, N.; Koike, K.; Komatsu, N.; Kumakiri, C.; Kumakiri, Ch.; Nakazato, M.; Watanabe, H.; Shinoda, N.; Okada, S.; Lyo, M. Alterations of serum levels of brain-derived neurotrophic factor (BDNF) in depressed patients with or without antidepressants. Biol. Psychiatry., 2003, 54, 70-75.

[24] AL-Ayadhi, L. Autoimmune connection of autism in Riyadh area. Neurosciences, 2005, 10 (4), 265-267

[25] AL-Ayadhi, L. Proinflammatory cytokines in autistic children in Central Saudi Arabia. Neurosciences, 2005, 10 (2), 155-158

[26] Singh, V.K.; Cheng, J.F. Immunoreactive S100 proteins of blood immunocytes and brain cells. J. Neuroimmunol., 1996, 64,135-139.

[27] Singh, V.K.; Fudenberg, H.H.; Emerson, D.; Coleman, M. Immunodiagnosis and immunotherapy in autistic children. Ann. N. Y. Acad. Sci., 1988, 540, 602-604
[28] Warren, R.P.; Foster, A.; Margaretten, N.C. Reduced natural killer cell activity in autism. J. Am. Acad. Child Adolesc. Psychiatry, 1987, 26, 333-335.

[29] Warren, R.P.; Yonk, J.; Burger, R.W.; Odell, D.; Warren, W. L. positive $\mathrm{T}$ cells in autism Association with decreased plasma levels of the complement C4B protein. Neuropsychobiology, 1995, 31, 53-57.

[30] Singh, V.K.; Warren, R.P.; Odell, J.P.; Warren, W. L.; Cole, P. Antibodies to myelin basic protein in children with autistic behavior. Brain Behav. Immun., 1993, 7, 97-103

[31] Plioplys, A.P.; Greaves, A.; Kazemi, A.; Silverman, E. Immunoglobulin reactivity in autism and Rett's syndrome. Dev. Brain Dysfunct., 1994, 7, 12-16

(C) Laila AL-Ayadhi; Licensee Bentham Open.

This is an open access article licensed under the terms of the Creative Commons Attribution Non-Commercial License (http://creativecommons.org/licenses/by-nc/3.0/) which permits unrestricted, non-commercial use, distribution and reproduction in any medium, provided the work is properly cited. 